\title{
DESKRIPSI KLON TANAMAN UBI KAYU (Manihot esculenta Crantz) YANG DITANAM PETANI DI ENAM KABUPATEN DI PROVINSI LAMPUNG
}

\author{
CASSAVA (Manihot esculenta Crantz) \\ CLONES DESCRIPTION CULTIVATED IN SIX DISTRICTS IN \\ LAMPUNG PROVINCE
}

\author{
Dany Pranowo ${ }^{1}$, Kukuh Setiawan $^{2}$, Syamsoel Hadi $^{3}$, Erwin Yuliadi ${ }^{4}$ \\ ${ }^{1}$ Mahasiswa Jurusan Agroteknologi; Fakultas Pertanian, Universitas Lampung \\ E-mail: Dany Pranowo10@gmail.com
}

Dikirim 5 September 2021, Direvisi 12 Oktober 2021, Disetujui 29 November 2021

\begin{abstract}
Abstrak: Penelitian ini dilakukan dengan melakukan pengumpulan data klon ubi kayu dengan melakukan survei di Way Kanan, Lampung Tengah, Lampung Utara, Pringsewu, Tanggamus, dan Metro). Penentuan kabupaten sampel dilakukan dengan metode acak terarah berdasarkan luasan budidaya. Pengambilan sampel desa dilakukan melalui rancangan sampling non-probablitas, yaitu sampling kebetulan (accidental sampling). Data primer diperoleh melalui wawancara kepada petani yang dijumpai di lokasi penelitian meliputi nama lokal, umur tanaman, dan penggunaan klon yang dibudidayaka. Data deskripsi karakteristik morfologis karakteristik vegetatif didapatkan melalui pengamatan langsung di lapangan dengan standarisasi yang ditetapkan oleh International Institute of Tropical Agriculture (IITA) yaitu "Selected Morphological and Agronomic Descriptors for the Characterization of Cassava" oleh Fukuda, dkk. (2010). Ditemukan 15 klon dari 6 kabupaten/kota, di Kabupaten Lampung Tengah ditemui 3 klon ubi kayu (Barokah, Thailand, dan Kasesat), Tanggamus 2 klon (Martapuro dan Baturaja), Pringsewu 2 klon ( Melati dan Pringsewu-1), Way Kanan 3 Klon (S.R. Lowo, Way Kanan -1 dan Way Kanan-2), Kota Metro 2 klon (Manalagi dan Klenteng) dan di Lampung Utara ditemui 3 klon (Roti, Udang, dan Ketan). Analisis klaster dilakukan untuk mengetahui struktur populasi suatu kelompok individu termasuk kemiripan (similarity) atau jarak genetik (distance) dan penyebaran kelompok tertentu dalam populasi dengan menggunakan software SPSS Statistics 23. Terdapat 8 level, klon yang memiliki tingkat kesamaan karakter terbesar adalah klon Martapuro dan S.R Lowo.
\end{abstract}

Kata kunci: Deskripsi klon, ubi kayu (Manihot esculenta Crantz), inventarisasi

Abstract: This research was conducted by collecting data on cassava clones by conducting a survey in Way Kanan, Central Lampung, North Lampung, Pringsewu, Tanggamus, and Metro. The district was choosed by randomized directed sampling method. Village sampling done by non-probability sampling design named accidental sampling. Primary data was obtained by interviews with farmers found at the research location including local names, plant age, and use of cassava clones that were cultivated.Morphological of vegetative characteristic data was obtained through direct observation in location based standardization set by the International Insitute of Tropical Agriculture (IITA), namely "Selected Morphological and Agronomic Descriptor for the Characterization of Cassava" by Fukuda, et al (2010). There were 15 clones found from 6 districts /cities, in Central Lampung 3 cassava clones were found (Barokah, Thailand, and Kasesat), 2 clones in Tanggamus (Martapuro and Baturaja), 2 clones in Pringsewu (Melati and Pringsewu-1), 3 Clones in Way Kanan (SR Lowo, Way Kanan -1 and Way Kanan-2), 2 clones in Metro City (Manalagi and Klenteng) and in North Lampung there are found 3 clones (Roti, Udang, and Ketan). Cluster analysis was carried out to determine the population structure of an individual group including similarity or genetic distance and the distribution of certain groups in the population using SPSS Statistics 23 software. There are 8 levels, the clones that have the greatest level of character similarity are the Martapuro and SR Lowo.clones.

Keywords: Clones description, cassava (Manihot esculenta Crantz), inventarization

\section{PENDAHULUAN}

Ubi kayu (Manihot esculenta Crantz) berasal dari Benua Amerika tepatnya dari Brazil. Tanaman pangan berupa perdu ini di Indonesia merupakan makanan pokok penting ketiga setelah padi dan jagung. Kandungan gizi ubi kayu cukup lengkap, meliputi karbohidrat, lemak, protein, serat makanan, vitamin $(\mathrm{B} 1, \mathrm{C})$, dan mineral $(\mathrm{Fe}$, 
F, Ca). Selain itu, ubi kayu mengandung tanin yang merupakan senyawa non-gizi (Soehardi, 2004).

Pemanfaatan ubi kayu tidak terbatas pada pemenuhan kebutuhan pangan, ubi kayu banyak dimanfaatkan sebagai bahan baku industri. Ubi kayu di sektor industri berpotensi untuk diolah menjadi berbagai produk turunan diantaranya gaplek, pellet, tepung tapioka, tepung mocaf, tepung aromatik, dan monosodium glutamate. Melalui proses fermentasi, kandungan pati pada singkong dapat diolah menjadi sumber energi terbarukan yaitu bioethanol. Selain itu, pati ubi kayu juga dimanfaatkan sebagai bahan pengikat (binder) dan pengisi (filler) pada pil, tablet dan kapsul pada industri farmasi (Yusuf, 2008).

Demikian besarnya potensi pemanfaatan ubi kayu namun hingga saat ini belum ada pendataan mengenai klonklon ubi kayu yang dibudidayakan utamanya di Provinsi Lampung. Sehingga diperlukan eksplorasi untuk mendata klonklon yang dibudidayakan untuk pemanfaatan yang lebih luas. Selama ini perbanyakan tanaman ubi kayu yang dilakukan oleh petani adalah melalui perbanyakan vegetatif dengan stek batang, karena umumnya tanaman ubi kayu di panen sebelum berbunga. Selain itu perbanyakan melalui stek batang juga lebih mudah dilakukan. Tanaman yang diperbanyak secara vegetatif akan mempunyai sifat yang sama dengan induknya. Perbanyakan secara generatif hanya dilakukan untuk kepentingan pemuliaan tanaman. Hal ini menyebabkan persilangan tanaman ubi kayu secara alami di areal pertanaman jarang terjadi meskipun tidak jarang dalam satu areal pertanaman terdapat lebih dari satu klon ubi kayu.

Provinsi Lampung sebagai produsen ubi kayu di Indonesia mempunyai beragam klon ubi kayu, akan tetapi pada umumnya klon yang ditanam oleh petani adalah klon Thailand dan Kasetsart. Hal tersebut merupakan upaya untuk memenuhi kebutuhan industri tapioka di Provinsi Lampung. Akibatnya klon-klon ubi kayu lainnya menjadi kurang diminati untuk ditanam oleh petani. Padahal ubi kayu dapat dimanfaatkan menjadi berbagai bahan baku industri hilir. Kurang diminatinya klon-klon selain Thailand dan Kasetsart kemungkinan karena petani belum mengetahui kelebihan dan sasaran penjualan klon-klon tersebut. Untuk itu diperlukan deskripsi mengenai karakter klon ubi kayu yang ada di Provinsi Lampung sebagai rujukan bagi petani dalam menentukan klon yang akan ditanam.

Hingga saat ini belum ada upaya untuk mendata dan menginventarisasi klon-klon yang tersebar di Provinsi Lampung, meskipun Provinsi Lampung merupakan produsen terbesar singkong di Indonesia. Kegiatan inventarisasi merupakan kegiatan turun ke lapangan mengumpulkan data tentang jenis-jenis tanaman yang ada di daerah tersebut. Kegiatan inventarisasi ini meliputi kegiatan eksplorasi dan identifikasi. Kegiatan inventarisasi dan karakterisasi terhadap morfologi genotipe tanaman ubi kayu diharapkan dapat mengungkapkan potensi unggulan tanaman ini dan informasi yang didapatkan digunakan sebagai acuan untuk mengenalkan jenis-jenis ubi kayu yang ada di daerah ini dalam ruang lingkup yang lebih luas. Deskripsi klon merupakan informasi gambaran suatu kelompok tanaman mengenai variasi sifat pertumbuhan vegetatif dan generatif maupun sifat morfologi tanaman yang dihasilkan melalui proses karakterisasi (Yuniarti, 2011).

Selain untuk petani, bagi pemulia tanaman kegiatan inventarisasi merupakan langkah pengumpulan plasma nutfah yang sangat penting. Menurut Karsono (2008), pemuliaan tanaman sendiri didefinisikan sebagai serangkaian kegiatan penelitian dan pengembangan genetik tanaman (modifikasi gen ataupun kromosom) untuk 
merakit kultivar/varietas unggul yang berguna bagi kehidupan manusia. Peran dari plasma nutfah adalah sebagai sumber daya genetik, makin beragam plasma nutfah yang tersedia maka akan memberikan koleksi yang lebih baik untuk keragaman hasil pemuliaan tanaman ubi kayu. Plasma nutfah adalah substansi yang terdapat pada suatu kelompok makhluk hidup yang merupakan sumber sifat keturunan yang dapat dirakit untuk menciptakan jenis unggul atau kultivar yang baru (Syukur, dkk. 2015).

Penelitian ini bertujuan untuk :

1. Mendeskripsikan karakter kualitatif klon-klon ubi kayu yang dibudidayakan oleh petani di Provinsi Lampung.

2. Mengidentifikasi klon ubi kayu sesuai peruntukannya (industri tapioka atau produk olahan makanan).

\section{METODOLOGI}

Penelitian ini dilaksanakan dengan melakukan survei pada areal pertanaman ubi kayu di 6 kabupaten di Provinsi Lampung, yaitu. Way Kanan, Lampung Tengah, Lampung Utara, Pringsewu, Tanggamus, dan Metro. Penelitian dilaksanakan pada bulan Desember 2018April 2019.

Alat-alat yang digunakan dalam penelitian ini adalah cangkul, jangka sorong, meteran, mistar, alat tulis, spidol, cutter, label, dan kamera digital

Penentuan kabupaten yang dipilih menjadi sampel ditentukan melalui metode acak terarah berdasarkan luasan budidaya, 3 sampel diwakili oleh kabupaten dengan luasan budidaya lebih dari $10.000 \mathrm{Ha}$ yang mewakili sentra produksi tapioka dan 3 sampel diwakili kabupaten dengan luasan kurang dari $10.000 \mathrm{Ha}$ yang mewakili kabupaten sentra industri olahan makanan, sehingga diperoleh sampel kabupaten Lampung Tengah, Lampung Utara, dan Way Kanan yang mewakili sentra industri tapioka, Kota Metro, Kabupaten
Pringsewu, dan Tanggamus. Demikian pula halnya dengan pengambilan sampel desa untuk masing-masing kecamatan, pengambilan sampel petani dilakukan melalui rancangan sampling nonprobablitas, yaitu sampling kebetulan (accidental sampling) (Eunike, 2013). Berdasarkan petani pertama yang dijumpai ditetapkan petani kedua melalui informasi yang diperoleh dari petani pertama.

Data primer diperoleh melalui wawancara kepada petani yang dijumpai di lokasi penelitian meliputi nama lokal, umur tanaman, dan informasi lain seperti rasa dan lain-lain. Setiap lokasi yang diamati diwakili oleh satu tanaman untuk setiap klon ubi kayu, yang diambil secara acak tidak sistematis dengan memilih tanaman sehat yang secara rata-rata tumbuh dengan baik dan diusahakan bukan tanaman pinggir. Tanaman yang diamati adalah tanaman yang telah berumur minimal 6 bulan. Informasi umur tanaman tersebut diperoleh dari petani, selain tampilan vegetatif dari tanaman yang telah berumur 6 bulan juga bisa diamati karakter ubinya. Penelitian ini menggunakan metode deskriptif yaitu mengidentifikasi karakter klon tanaman ubi kayu yang ditemukan.

Data yang dikumpulkan terdiri dari data primer yang diperoleh melalui pengamatan langsung di lapangan yaitu genotip-genotip ubi kayu yang ditemukan, lalu diamati secara morfologis karakteristik vegetatifnya yang menjadi penciri antara satu genotip dengan genotip lainnya. Pengamatan dilakukan pada batang,daun, dan ubi meliputi:

a) Daun (bentuk daun, warna daun, warna tangkai daun, warna tulang daun, jumlah anak daun, ukuran)

b) Batang (warna batang muda, batang tua, diameter batang)

c) Ubi (warna kulit luar ubi, warna kulit dalam ubi, warna ubi) 
Berdasarkan informasi yang diperoleh dari petani, kemudian ubi kayu digolongkan berdasarkan penggunaannya (industri tapioka atau produk olahan pangan). Hubungan kekerabatan antarklon ditentukan melalui analisis klaster karakter-karakter kualitatif yang terlebih dahulu dikonversi. Berdasarkan analisis klaster tersebut dibuat dendogram yang menggambarkan kemiripan karakter satu sama lain. Analisis klaster dilakukan untuk mengetahui struktur populasi suatu kelompok individu termasuk kemiripan (similarity) atau jarak genetik (distance) dan penyebaran kelompok tertentu dalam populasi dengan menggunakan software SPSS Statistics 23. Karakter kuantitatif tidak dimasukkan ke dalam variabel analisis dikarenakan perbedaan umur satu sampel dengan sampel yang lain.

\section{HASIL DAN PEMBAHASAN}

Berdasarkan survei yang telah dilakukan, diperoleh 15 klon dari 6 kabupaten/kota tersebut yang antar klonnya berbeda satu sama lain. Di Kabupaten Lampung Tengah ditemui 3 klon ubi kayu (Barokah, Thailand, dan Kasetsart), Tanggamus 2 klon (Martapuro dan Baturaja), Pringsewu 2 klon ( Melati dan 1 klon tidak diketahui nama lokalnya (selanjutnya disebut Pringsewu-1), Way Kanan 3 Klon (S.R. Lowo dan 2 klon tidak diketahui nama lokalnya (selanjutnya disebut Way Kanan-1 dan Way Kanan 2, Kota Metro 2 klon ( Manalagi dan Klenteng) dan di Lampung Utara ditemui 3 klon (Roti, Udang, dan Ketan). Perbedaan antar satu klon dengan klon yang lain terletak pada karakter daun, batang, atau ubi. Klon ubi kayu dengan karakter yang sama tidak dideskripsikan kembali meskipun ditemukan di kabupaten lain. Hal ini dilakukan dengan pertimbangan waktu pengamatan yang cukup lama sehingga dianggap kurang efisien untuk pengamatan ulang klon yang karakternya sama. Contohnya klon ubi kayu Thailand dan Kasetsart yang ditemui hampir di seluruh kabupaten/kota, bila diamati justru akan menutup kemungkinan untuk menemukan klon-klon lain. Klonklon ubi kayu yang ditemui di 6 kabupaten/kota di Provinsi Lampung berdasarkan karakter kualitatif daun, batang, dan ubi. Berikut merupakan deskripsi klon ubi kayu dari setiap kabupaten/kota.

\section{A. Kabupaten Lampung Tengah}

Kabupaten Lampung Tengah merupakan kabupaten dengan produksi ubi kayu terbesar di Provinsi lampung pada tahun 2017 dengan luasan budidaya $68.720 \mathrm{Ha}$ dan total produksi 1.730 .156 Ton. Di Kabupaten Lampung Tengah ditemukan 3 klon ubi kayu yaitu Klon Barokah, Thailand dan Kasetsart. Klon Barokah ditemukan di Desa Trimurjo, Kecamatan Trimurjo, sementara klon Thailand dan Kasetsart ditemukan di Desa Sidokerto, Kecamatan Bumi Ratu Nuban. Semua klon yang ditemukan diperuntukan memenuhi bahan baku industri tapioka. Hal tersebut dikarenakan Lampung Tengah merupakan kabupaten dengan luasan pertanaman dan produksi ubi kayu tertinggi di Provinsi Lampung. Sebagian besar pabrik tapioka juga terletak di kabupaten ini, yang berpengaruh terhadap klon yang ditanam berorientasi pada pemenuhan bahan baku produk tersebut. Klon Thailand dan Kasetsart sampai saat ini merupakan klon yang paling umum dibudidayakan untuk pemenuhan kebutuhan industri tapioka dikarenakan daya hasilnya tinggi.

Klon Barokah memiliki karakter daun berwarna hijau gelap, berbentuk lancelote, dengan tunas pucuk hijau keunguan, warna tulang daunnya hijau kemerahan kurang dari setengah lobus. Karakter batangnya kulit luar berwarna coklat terang, warna korteksnya hijau terang, warna epidermis cream, dan warna pada akhir percabangan hijau keunguan. Berdasarkan karakter ubi, klon barokah memiliki kulit ubi berwarna putih juga dengan warna korteks ubi , 
ubinya berwarna cream dengan bentuk silinder. Klon Barokah berdasarkan informasi dari petani setempat memiliki produksi yang lebih tinggi dari Klon Thailand dan Kasetsart akan tetapi kadar patinya lebih rendah.

Klon Thailand memiliki daun dengan karakter tunas pucuknya berwarna hijau muda, daun berwarna hijau gelap berbentuk lancelote, lobusnya berjumlah 5, dan warna tulang daunnya hijau kemerahan. Berdasarkan karakter batang korteksnya berwarna hijau terang, warna kulit luar batang coklat terang, epidermisnya berwarna cream, dan warna batang pada ujung percabangannya hijau. Klon Thailand memiliki kulit ubi berwarna coklat terang dengan korteks berwarna cream, ubinya berwarna cream dan berbentuk kerucut. Klon ubi kayu Thailand (UJ-3) merupakan klon introduksi dari Thailand yang dirilis 25 Februari 2000 . Kadar pati klon ini cukup tinggi yaitu 20$27 \%$ dengan potensi hasil 20-35 t/ha dan dapat dipanen pada umur 8-10 bulan. Klon ini banyak ditanam di Provinsi Lampung untuk memenuhi kebutuhan industri tapioka.

Klon ubi kayu Kasetsart memiliki karakter daun berwarna hijau gelap, berbentuk lancelote, dengan 7 lobus, warna tunas pucuk hijau keunguan, dan warna tulang daunnya hijau. Kulit luar batangnya berwarna perak, dengan korteks berwarna hijau gelap, warna epidermisnya coklat muda, dan warna batang pada ujung percabangan berwarna hijau. Kulit ubinya coklat terang dengan korteks cream, ubi berwarna putih berbentuk silinder. Kadar pati klon ini cukup tinggi yaitu 19-30\% dengan potensi hasil 25-38 t/ha dan dipanen pada umur 9-10 bulan.

\section{B. Kabupaten Tanggamus}

Terdapat dua klon ubi kayu yang di temukan di Kabupaten Tanggamus, di Desa Sukajaya, yaitu klon Martapuro dan Baturaja disajikan pada Tabel 18.
Klon Martapuro mempunyai daun berwarna hijau gelap dengan bentuk lancelote, warna tunas pucuk hiau keunguan, dan warna tulang daun hijau. Kulit luar batangnya berwarna coklat terang, korteks batang berwarna hijau gelap, epidermis batang coklat muda, dan warna batnag pada ujung percabnagan hijau. Ubinya berbentuk kerucut silindris, kulit luarnya berwarna coklat terang, dengan korteks berwarna krim/putih dan ubinya berwarna cream.

Klon Baturaja memiliki daun dengan karakter berwarna hijau terang, berbentuk lancelote, lobus berjumlah 7 , tulang daun berwarna hijau kemerahan kurang dari setengah lobus, dan warna tunas pucuk hijau muda. Warna kulit luar batangnya keemasan dengan korteks hijau terang, epidermis berwarna coklat muda, dan warna pada batang di ujung percabangan berwarna hijau.

\section{Kabupaten Pringsewu}

Ditemukan 2 klon di Kabupaten Pringsewu, yaitu Melati dan1 klon tidak diketahui namanya sehingga untuk memudahkan penyebutan selanjutnya ditulis sebagai Pringsewu-1. Klon Pringsewu-1 memiliki bentuk daun elliptical lancelote berwarna hijau gelap dengan warna tunas pucuk hijau keunguan dan warna tulang daun hijau. Klon ini memiliki kulit luar batang berwarna abuabu dengan korteks berwarna hijau gelap, epidermis batang berwarna krim, dan batang pada ujung percabangan berwarna hijau. Ubinya berbentuk lonjong mengerucut, kulit luar ubi berwarna coklat, terang, korteks ubi dan daging ubi berwarna krim.

Klon melati memili daun berwarna hijau terang berbentuk lancelote, warna tulang daunnya hijau, dan warna tunas pucuknya juga berwarna hijau. Batangnya mempunya kulit luar berwarna coklat gelap, korteks batang berwarna hijau terang, epidermis batang berwarna krim, 
dan warna batang pada ujung percabangan hijau. Ubinya berbentuk silinder, daging ubi berwarna krim, korteks ubi berwarna krim, dan kulit luar ubi berwarna coklat gelap.

\section{Kabupaten Way Kanan}

Ditemukan 3 Klon di Kabupaten Waykanan, yaitu S.R. Lowo dan 2 klon tidak diketaui nama lokalnya, sehingga untuk memudahkan penyebutan selanjutnya ditulis sebagai Way Kanan-1 dan Way Kanan-2. Klon Way Kanan-1 memiliki daun berbentuk lancelote, berwarna hijau gelap, warna tulang daunnya hijau kemerahan dan tunas pucuknya berwarna hijau keunguan. Kulit luar batangnya berwarna abu-abu, korteksnya berwarna hijau gelap, epidermis batangnya coklat muda, dan warna pada ujung percabangan hijau keunguan. Ubinya berbentuk silinder mengerucut, daging ubi berwarna krim, kulit luar berwarna coklat terang, dan korteks ubi berwarna krim.

Klon Way Kanan-2 memiliki daun berwarna hijau gelap berbentuk lancelote, memiliki 7 lobus, warna tulang daunnya hijau kemerahan, dan warna tunas pucuknya hijau keunguan. Kulit luar batang berwarna coklat terang, korteks batang berwarna hijau gelap, epidermis berwarna krim, dan warna pada ujung percabangan hijau keunguan. Ubi berbentuk silinder mengerucut, kulit ubi berwarna cream, korteks ubi berwarna krim, dan ubi berwarna putih.

Klon S.R Lowo memiliki daun berbentuk oblong lancelote berwarna hijau gelap, warna tulang daun hijau kemerahan, tunas pucuk berwarna hijau keunguan. Batangnya mempunyai kulit luar coklat terang, korteksnya hijau gelap, epidermisnya berwarna krim, dan warna pada ujung percabangan hijau keunguan. Ubinya berbentuk silindris mengerucut, kulit ubi berwarna coklat terang, korteks dan daging ubi berwarna krim.

\section{E. Kota Metro}

Ditemukan 2 klon dari Kota Metro yaitu Klenteng dan Manalagi tepatnya di Kecamatan Metro Selatan. Klon Klenteng memiliki bentuk daun oblong lancelote berwarna hijau gelap, warna tulang daun hijau kemerahan, dan warna tunas pucuk hijau keunguan. Batangnya berwarna perak, korteks berwarna hijau gelap, epidermis berwarna coklat tua, dan warna pada ujung percabangan hijau keunguan. Ubi berwarna hijau keunguan. Ubi berbentuk silindris, kulit luar ubi berwarna coklat gelap, korteks ubi dan daging ubi berwarna krim.

Klon Manalagi mempunyai bentuk daun oblong lancelote berwarna hijau gelap, tulang daun berwarna hijau, dan warna tunas pucuk hijau. Batangnya mempunyai warna kulit luar hijau kekuningan, korteks hijau terang, epidermis coklat muda, dan warna batang pada ujung percabangan hijau. Bentuk ubi silinder dengan warna kulit luar coklat gelap, korteks dan daging ubi berwarna krim.

\section{F. Kabupaten Lampung Utara}

Di Kabupaten Lampung Utara ditemukan 3 klon yaitu Klon Roti, Udang, dan Ketan. Ketiga klon tersebut merupakan ubi kayu makan. Klon ketan memiliki daun berbentuk lancelote dengan warna hijau gelap, warna tunas pucuk hijau keunguan, dan warna tulang daun hijau kemerahan. Warna luar batang hijau kekuningan, korteks batang hijau terang, epidermis batang coklat muda, dan warna batang pada ujung percabangan hijau. Ubinya berbentuk silinder dengan warna kulit luar coklat gelap, korteks dan warna ubi krim.

Klon Roti memiliki daun berbentuk obovate lancelote, berwarna hijau gelap, tulang daun berwarna hijau kemerahan, 
dan warna tunas pucuknya ungu. Batangnya mempunyai kulit luar berwarna perak, korteksnya hijau gelap, epidermis krim, dan warna batang pada ujung percabnagan hijau keunguan. Ubinya berbentuk kerucut, kulit luar, korteks, dan daging ubi berwarna krim.

Klon Udang mempunyai bentuk daun lurus, berwarna hijau gelap, lobusnya berjumlah 7, warna tulang daun hijau, dan warna tunas pucuknya hijau keunguan. Batangnya mempunyai kulit luar berwarna perak, korteks hijau gelap, epidermis krim, dan warna batang pada ujung percabangan hijau.

Berdasarkan data yang diperoleh, diketahui perbedaan karakter kualitatif dari klon-klon ubi kayu yang tersebar berdasarkan karakter daun, batang, dan ubinya. Berdasarkan data tersebut kemudian ditentukan nilai koefisien kemiripan karakter kualitatifnya dengan mengonversi hasil pengamatan kualitatif dalam skor angka mengacu pada panduan karakterisasi ubi kayu Fukuda, dkk. (2010). Karakter kualitatif dibuat analisis Klaster menggunakan software SPSS Statistics 23.

Tabel 1. Kombinasi kekerabatan 15 klon ubi kayu

\begin{tabular}{llccc}
\hline \multirow{2}{*}{ No } & \multicolumn{1}{c}{ Aksesi } & \multicolumn{2}{c}{ Kombinasi Kelompok } & Nilai \\
& & Klon A & Klon B & koefisien \\
\hline 1 & Barokah & 4 & 10 & 0.104 \\
2 & Thailand & 8 & 9 & 2.029 \\
3 & Kasetsart & 3 & 7 & 2.029 \\
4 & Martapuro & 4 & 6 & 2.081 \\
5 & Baturaja & 8 & 11 & 2.174 \\
6 & Pringsewu-1 & 12 & 13 & 3.590 \\
7 & Melati & 2 & 5 & 4.242 \\
8 & Way Kanan 1 & 8 & 14 & 4.569 \\
9 & Way Kanan-2 & 4 & 8 & 6.453 \\
10 & S.R. Lowo & 2 & 4 & 9.862 \\
11 & Klenteng & 3 & 12 & 10.418 \\
12 & Manalagi & 2 & 3 & 10.841 \\
13 & Ketan & 2 & 15 & 13.804 \\
14 & Roti & 1 & 2 & 28.491 \\
15 & Udang & 1 & 4 & 30.169 \\
\hline
\end{tabular}

Nilai koefisien pada Tabel 1 menyatakan jarak (distance) antarklon yang dibandingkan. Semakin kecil nilai koefisien, maka nilai kesamaan (similiarity) semakin tinggi artinya semakin banyak kesamaan karakter yang dimiliki antar kedua klon. Sebaliknya, jika nilai koefisen semakin tinggi maka karakter klon semakin berbeda. Nilai koefisien ini juga menggambarkan tingkat keberhasilan jika klon tersebut di silangkan, semakin rendah nilai koefisien semakin tinggi tingkat kesuksesan penyilangan. Sebaliknya semakin tinggi nilai koefiesiennya maka hasil penyilangan akan semakin beragam.

Pada tabel tersebut diketahui bahwa klon yang paling mirip adalah klon Martapuro dan S.R Lowo, dan klon yang paling rendah tingkat kemiripannya adalah klon Barokah dan Martapuro. Berdasarkan nilai koefisien pada Tabel 6, maka diperoleh hasil dendrogram yang disajikan pada Gambar 1.

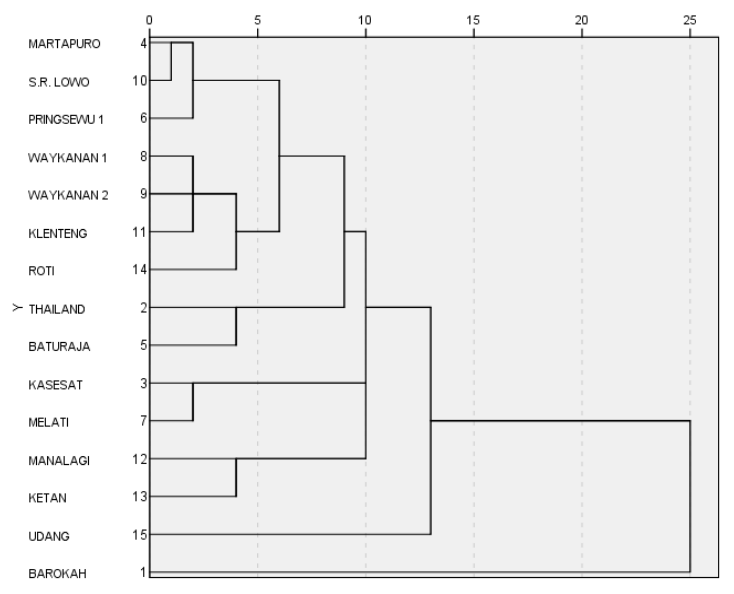

Gambar 1. Dendogram kekerabatan 15 klon ubi kayu yang ditemukan.

Berdasarkan diagram pada Gambar 1 tersebut kemudian dikelompokkan menurut level, klon-klon yang berada pada garis vertikal yang sejajar dikelompokan pada level yang sama. Garis horizontal menyatakan persentase perbedaan antar klon, semakin ke arah kanan maka tingkat perbedaannya semakin tinggi. Dari gambar tersebut diketahui sesuai nilai koefisien pada Tabel 15. Pengelompokan klon-klon tersebut ke dalam level-level disajikan pada Tabel 16. 
Tabel 2. Pengelompokan 15 klon ubi kayu berdasarkan karakter kualitatif

\begin{tabular}{cl}
\hline Level & \multicolumn{1}{c}{ Klon } \\
\hline I & $\begin{array}{l}\text { Melati, Manalagi, Ketan, Udang, } \\
\text { Barokah. } \\
\text { Thailand, Baturaja, Kasetsart, Melati, } \\
\text { Manalagi, Ketan, Udang }\end{array}$ \\
II & $\begin{array}{l}\text { Klenteng, Roti, Thailand, Baturaja, } \\
\text { Kasetsart, Melati, Manalagi }\end{array}$ \\
IV $\quad \begin{array}{l}\text { Waykanan 1, Waykanan 2, Klenteng } \\
\text { Roti, Thailand, }\end{array}$ \\
V & $\begin{array}{l}\text { S.R. Lowo, Pringsewu 1, Waykanan 1, } \\
\text { Waykanan 2, Klenteng. }\end{array}$ \\
I & $\begin{array}{l}\text { Way Kanan 2, Klenteng, Roti, Thailand, } \\
\text { Baturaja, Manalagi, Ketan. } \\
\text { Martapuro, S.R Lowo, Pringsewu 1, } \\
\text { Waykanan 1, Waykanan 2, Klenteng, }\end{array}$ \\
VIII & $\begin{array}{l}\text { Kasetsart, Melati. } \\
\text { Martapuro, S.R Lowo. }\end{array}$ \\
\hline
\end{tabular}

Pengelompokan klon pada Tabel 16 dibagi menjadi 8 level berdasarkan tingkat kemiripan (simialirity) klon-klon tersebut. Semakin tinggi level, maka tingkat kemiripannya semakin tinggi. Sesuai dengan koefisien pada Tabel 15 klon yang paling tinggi kemiripannya adalah Martapuro dan S.R. Lowo.

\section{KESIMPULAN}

Berhasil diidentifikasi 15 klon dari 6 kabupaten/kota yaitu, Kabupaten Lampung Tengah ditemui 3 klon ubi kayu (Barokah, Thailand, dan Kasetsart), Tanggamus 2 klon (Martapuro dan Baturaja), Pringsewu 2 klon ( Melati dan 1 klon tidak diketahui nama lokalnya), Way Kanan 3 Klon (S.R. Lowo dan 2 klon tidak diketahui nama lokalnya), Kota Metro 2 klon ( Manalagi dan Klenteng) dan di Lampung Utara ditemui 3 klon (Roti, Udang, dan Ketan). Dari 15 Klon yang ditemukan, 3 klon (Barokah, Thailand, dan Kasetsart) diperuntukan untuk produksi tapioka dan 12 klon (Martapuro, Baturaja, Melati, Pringsewu-1, S.R. Lowo, Way Kanan-1, Way Kanan-2, Manalagi, Klenteng, Roti, Udang, dan Ketan) klon diperuntukan untuk bahan baku industri makanan.
Masih terdapat klon-klon di kabupaten/kota tersebut yang belum teridentifikasi dikarenakan keterbatasan daya jelajah peneliti, pada saat survey dilakukan pemilik tanaman tidak dapat ditemui, dan umur tanaman tidak memenuhi syarat untuk dijadikan sampel. Dengan demikian, diperlukan penelitian lanjutan untuk mengidentifikasi lebih banyak klon yang tersebar di Provinsi Lampung dengan mengacu pada hasil penelitian ini sehingga klon yang sama tidak perlu diidentifikasi ulang. Ketidakseragaman umur tanaman juga membuat pengujian daya hasil tidak dapat dilakukan, sehingga diperlukan penelitian lanjutan untuk mengetahui daya hasil dari masing-masing klon. Untuk memastikan perbedaan fenotipik bukan disebabkan oleh pengaruh lingkungan, juga diperlukan uji DNA.

\section{DAFTAR PUSTAKA}

Atmojo, S.W. 2006. Peranan Bahan Organik terhadap Kesuburan Tanah dan Upaya Pengelolaannya. Sebelas Maret University Press. Surakarta.

Badan Pusat Statistik. 2017. Lampung Dalam Angka. BPS Provinsi Lampung. Bandar Lampung.

Bradbury, J.H. dan Warren, D.H. 1988. Chemistry of Tropical Root Crops: Significance for Nutrition and Agriculture in The Pacific. ACIAR. Canberra.

Direktorat Jenderal Bina Produksi Tanaman Pangan. 2002. Agribisnis Ubi Jalar Cilembu. Direktorat KacangKacangan dan Umbi-umbian. Jakarta.

Eunike, A. 2013. Statistika Industri 1. dari www.aeunike.lecture.ub.ac.id pada tanggal 9 April 2019.

Ferrero, M.T dan Villegas L. 1992. Effect of rainfall on $\mathrm{HCN}$ content in cassava roots. Prosiding CBN. 25-28 August 
1992; Cartagena de Indias, Colombia. Cali (CO): CIAT. hlm 433-437.

Fukuda, W.M.G., Guevara, C.L., Kawuki, R., dan Ferguson, M.E. 2010. Selected Morphological and Agronomic Descriptors for The Characterization of Cassava. International Institute of Tropical Agriculture (IITA). Ibadan, Nigeria.

Hasyim, A dan Yusuf, M. 2008. Difersifikasi Produk Ubi Kayu Sebagai Bahan Pangan Subtitusi Beras. Badan Litbang Pertanian. Malang.

Karsono, N. 2008. Peran Pemuliaan Tanaman dalam Meningkatkan Produksi Pertanian di Indonesia. http://Indoplasma.or.id/. Diakses 20 Juni 2019.

Moenandir, J. 2010. Ilmu Gulma. Universitas Brawijaya Press. Malang. $162 \mathrm{hlm}$.

Oladosu, Y., Rafii, M.Y., Abdullah, N., Hussin, G., Ramli, A., Rahim, H.A., Miah, G., dan Usman, M. 2016. Principle and application of plant mutagenesis in crop improvement: a review. Biotechnol. Biotechnol. Equip. hal. 1-16.

Soehardi, Soenarso. 2004. Memelihara Kesehatan Jasmani Melalui Makanan. ITB. Bandung:

Suharno, Djasmin, Rubiyo, dan Dasiran. 1999. Budi Daya Ubikayu. Badan Peneliti dan Pengembangan Pertanian. Kendari.

Sundari, T. 2010. Petunjuk Teknis Pengenalan Varietas Unggul dan Teknik Budidaya Ubi Kayu. Balai Penelitian Tanaman Kacang-kacangan dan Ubi-ubian. Malang.

Suparman. 2014. Diversifikasi Pertanian dalam Proses Mempercepat Laju Pembangunan Nasional. Pustaka Sinar Harapan. Jakarta:

Suyamto dan J. Wargiono. 2006. Potensi dan Peluang Pengembangan Ubi kayu untuk Industri Bioetanol. Prosiding Lokakarya Pengembangan Ubi Kayu. Balitkabi. Malang.

Syukur, M., Sujiprihati, S. dan R. Yunianti. 2015. Teknik Pemuliaan Tanaman. Edisi Revisi. Penebar Swadaya, Jakarta.

Wargiono, J., Hasanuddin, A., dan Suyamto. 2006. Teknologi produksi ubi kayu mendukung industri bioethanol. Puslitbang Tanaman Pangan. Bogor. 42 hlm.

Yuniarti. 2011. Inventaris dan karakteristik morfologi tanaman durian (Durio zibthinus Murr) di Kabupaten Tanah Datar. Skripsi. FMIPA Biologi Universitas Sriwijaya

Henita A, (2018). Efektivitas Rencana Strategis Pengembangan Sumber Daya Lokal Berbasis Sumber Daya Lokal di Provinsi Lampung. Jurnal Inovasi Pembangunan Volume 08 No. 2.

Kristian S, (2015). Determinan Produksi, Konsumsi dan Harga Ubi Kayu Indonesia (Tahun Studi 1991-2013 Menggunakan Persamaan Simultan). Jurnal Inovasi Pembangunan Volume 03 No. 2. 
